\title{
Implementasi Bahasa Jurnalistik pada Media Siber (Analisis Wacana pada Berita Okezone.com Kanal Perjalanan)
}

\author{
Fatha Annisa ${ }^{1}$, Ahmad Junaidi ${ }^{*}$ \\ ${ }^{1}$ Fakultas Ilmu Komunikasi, Universitas Tarumanagara, Jakarta \\ Email: fatha.915180205@stu.untar.ac.id \\ ${ }^{2}$ Fakultas Ilmu Komunikasi, Universitas Tarumanagara, Jakarta* \\ Email: ahmadd@fikom.untar.ac.id
}

Masuk tanggal: 15-12-2021, revisi tanggal: 06-01-2022, diterima untuk diterbitkan tanggal: 16-01-2022

\begin{abstract}
The existence of online media is increasing. Online media is a product of cyber journalism that uses the internet to present news. In the stage of writing and editing news, the use of journalistic language becomes a very important aspect. However, online media often violates the rules of journalistic language. Okezone.com is one of the online media in Indonesia which still makes mistakes in applying journalistic language. This research was conducted to find out the language style of the Okezone.com Travel, analyze the implementation of journalistic language in their news, and find out how the editor handled errors in the application of journalistic language. The theories used include Journalistic Language, News, and Online Media. The research uses a qualitative research approach with discourse analysis research methods. The results show that Okezone.com's style is still guided by journalistic language, even though it is adjusted to the needs of reader segmentation and search engines. Several errors in the application of journalistic language were found in the news published by the Okezone.com Travel in the period 1 - 30 September 2021. News with errors will be withdrawn for correction and editing.
\end{abstract}

Keywords: journalistic language, news, online media, online media language style

\begin{abstract}
Abstrak
Keberadaan media siber kian menjamur. Jenis media ini merupakan produk cyber journalism yang memanfaatkan internet untuk menyajikan berita. Dalam tahap penulisan dan penyuntingan berita, penggunaan bahasa jurnalistik menjadi aspek yang sangat penting. Kendati demikian, media siber kerap melanggar kaidah bahasa jurnalistik. Okezone.com merupakan salah satu media siber di Indonesia yang masih melakukan kesalahan penerapan bahasa jurnalistik. Penelitian ini dilakukan untuk mengetahui gaya bahasa media siber Okezone.com kanal perjalanan, menganalisis pengimplementasian bahasa jurnalistik pada berita yang ditayangkan, serta mengetahui cara redaksi menangani kesalahan dalam penerapan bahasa jurnalistik. Teori yang digunakan diantaranya bahasa jurnalistik, berita, dan media siber. Penelitian menggunakan pendekatan penelitian kualitatif dengan metode penelitian analisis wacana. Hasil penelitian menunjukkan bahwa kanal perjalanan Okezone.com tetap berpedoman pada bahasa jurnalistik, meskipun gaya bahasanya disesuaikan dengan kebutuhan segmentasi pembaca serta mesin pencari. Beberapa kesalahan penerapan bahasa jurnalistik ditemukan dalam berita yang diterbitkan kanal perjalanan Okezone.com dalam rentang waktu 1 - 30 September 2021. Berita yang memiliki kesalahan akan ditarik kembali untuk diralat dan disunting.
\end{abstract}

Kata Kunci: bahasa jurnalistik, berita, gaya bahasa media siber, media siber 


\section{Pendahuluan}

Dewan Pers dalam website resminya mencatat Indonesia memiliki 833 media siber yang telah terverifikasi (Pers, n.d.). Media yang didefinisikan sebagai bentuk media komunikasi berbasis telekomunikasi serta multimedia ini merupakan produk jurnalisme siber yang mempunyai kegunaan sebagai penyedia fakta, informasi, berita, maupun peristiwa, yang memanfaatkan internet sebagai alat untuk menghasilkan serta mendistribusikan informasi dalam bentuk pemberitaan (Yundri \& Nasution, 2018).

Berita sendiri masuk dalam jajaran karya tulis yang dibuat oleh jurnalis atau praktisi media dan disiarkan dalam media pers. Penulisan berita tidak boleh terlepas dari aturan dan juga tata cara penulisan yang baik, sehingga menghasilkan karya jurnalistik yang sesuai dengan standar yang berlaku (Silalahi \& Susanto, 2020). Proses penyajian berita pada media siber terdiri dari beberapa tahap, yaitu peliputan atau pengumpulan informasi, penulisan, penyuntingan, dan pengunggahan. Tahap penulisan dan penyuntingan berita atau karya tulis jurnalistik tidak dapat dilakukan dengan sembarangan karena harus memperhatikan aspek bahasa (Yundri \& Nasution, 2018). Bahasa jurnalistik atau disebut juga bahasa pers merupakan bahasa yang digunakan oleh media massa.

Aryusmar mendefinisikan bahasa sebagai nyawa bagi media cetak, elektronik, maupun siber (Aryusmar, 2011). Bahasa jurnalistik atau disebut juga bahasa pers merupakan bahasa yang digunakan oleh media massa. Haris Sumadiria mengemukakan bahwa bahasa jurnalistik memiliki ciri jernih, demokratis, mengesampingkan kalimat pasif, meminimalisir penggunaan kata atau istilah teknis, dan tunduk pada kaidah serta etika bahasa baku (Sumadiria, 2018). Bahasa jurnalistik digunakan oleh wartawan, redaktur, maupun pengelola media massa dalam proses penyusunan, penyajian, penyiaran, serta penayangan berita dengan tujuan mempermudah masyarakat atau pembaca memahami isi dan maknanya (Sumadiria, 2006). Bahasa jurnalistik pada setiap media siber bervariasi sesuai dengan target pembaca dan ideologi media terkait (Fadilah \& Mony, 2020). Maka dari itu, ragam bahasa dapat pula dikatakan sebagai identitas atau ciri khas suatu media (Aryusmar, 2011).

Sayangnya media siber kerap kali melakukan pelanggaran dalam mengimplementasikan bahasa jurnalistik pada pemberitaannya (Fadilah \& Mony, 2020). Seperti contohnya Okezone.com, sebuah portal media yang berhasil menempati peringkat satu dalam kategori portal media online terpopuler di Indonesia berdasarkan Alexa.com, sebuah web analitik yang melihat ketenaran media berdasarkan kualifikasi suatu negara, maupun dunia (Alexa.com, n.d.). Kesalahan penerapan bahasa jurnalistik dalam informasi yang disampaikan oleh media online tentunya dapat berdampak negatif pada pembaca. Terlebih Okezone.com tercatat memiliki jumlah pembaca mencapai 31,3 juta pembaca bulanan di tahun 2021 (Pebrianto, 2021).

Dalam penelitian ini, penulis berpanduan pada 17 karakteristik bahasa jurnalistik yang dikemukakan oleh Haris Sumadiria. Selain itu, penulis menggunakan konsep berita dan media siber, khususnya gaya bahasa pada media siber serta umpan klik. Penelitian ini dilakukan untuk mengetahui gaya bahasa pada Kanal Perjalanan Okezone.com, pengimplementasian bahasa jurnalistik pada media siber terkait, serta mengkaji bagaimana cara Kanal Perjalanan Okezone.com mengatasi kesalahan dalam pengimplementasian bahasa jurnalistik. 
Fatha Annisa, Ahmad Junaidi: Implementasi Bahasa Jurnalistik pada Media Siber (Analisis Wacana pada Berita Okezone.com Kanal Perjalanan)

\section{Metode Penelitian}

Pendekatan penelitian yang digunakan penulis adalah kualitatif. Bogdan dan Taylor (dalam Moleong, 2011) mengartikan metode kualitatif sebagai prosedur penelitian yang menghasilkan data deskriptif berbentuk kata-kata tertulis atau lisan dari narasumber atau perilaku orang-orang yang diamati. Sementara itu untuk melakukan analisis terhadap topik yang diteliti, metode yang digunakan oleh penulis adalah analisis wacana. Sudut pandang pertama dalam analisis wacana yang dikemukakan Eriyanto menempatkan bahasa sebagai jembatan antara manusia dengan objek di luar dirinya. Maka, analisis wacana digunakan untuk menggambarkan tata aturan kalimat, bahasa, dan pengertian bersama (Eriyanto, 2006). Analisis wacana tersebut peneliti gunakan sebagai alat pembedah dalam menganalisa pengimplementasian bahasa jurnalistik dalam teks berita media siber Okezone.com kanal perjalanan.

Penelitian ini menetapkan 70 berita pada media siber Okezone.com kanal perjalanan edisi 1-30 September 2021 dan Salman Mardira selaku editor kanal perjalanan Okezone.com sebagai subjek penelitian. Editor pada Okezone.com merupakan orang yang bertugas untuk menyeleksi dan menyunting naskah berita sebelum dipublikasikan. Maka, editor dapat menjadi penentu sesuai atau tidaknya bahasa yang digunakan dalam sebuah berita yang dimuat dalam media siber dengan kaidah bahasa jurnalistik.

Langkah yang dilakukan oleh peneliti dalam mengolah data adalah observasi non-partisipan, wawancara semi terstruktur, dokumentasi, dan studi kepustakaan. Sedangkan teknik yang digunakan untuk menganalisis data penelitian ini merupakan reduksi data (menyeleksi berita dalam kanal perjalanan Okezone.com edisi 1-30 September 2021 sesuai dengan kriteria yang dibutuhkan dan menyaring informasi yang didapatkan melalui wawancara dengan narasumber), penyajian data (menganalisis bahasa jurnalistik pada judul dan isi berita, mengelompokkan hasil temuan, dan memasukkannya ke dalam tabel), dan verifikasi.

Penulis menggunakan metode ketekunan penelitian dan triangulasi dalam menguji keabsahan data. Teknik ketekunan pengamatan bertujuan menemukan ciriciri dan unsur-unsur dalam situasi yang sangat relevan dengan persoalan atau isu yang sedang dicari, lalu memfokuskan diri pada hal-hal tersebut secara terinci (Moleong, 2011). Dengan ketekunan pengamatan, peneliti mencari secara konsisten data yang tidak sesuai, menganalisis, memeriksa, dan mengolahnya. Sementara itu, teknik triangulasi yang digunakan peneliti adalah triangulasi sumber data, yang artinya pengujian keabsahan data yang telah dikumpulkan terhadap beberapa sumber berbeda (Sugiyono, 2015). Peneliti mengumpulkan data dari observasi dan dokumentasi, kemudian membandingkannya dengan data hasil wawancara dengan informan.

\section{Hasil Temuan dan Diskusi}

Bahasa jurnalistik adalah bahasa yang diaplikasikan praktisi media seperti wartawan, redaktur, atau pengelola media massa dalam proses penyusunan, penyajian, penyiaran, serta penayangan berita, dan bertujuan untuk memudahkan publik mengerti dan menangkap isi maupun maknanya (Sumadiria, 2006). Bahasa jurnalistik bersifat tunduk pada bahasa baku sesuai dengan Ejaan Yang 
Disempurnakan (EYD) dan memperhatikan kaidah-kaidah tata bahasa serta tanda baca yang benar. Penggunaan bahasa jurnalistik telah diatur Persatuan Wartawan Indonesia (PWI) dan kode etik jurnalistik. Ada 17 karakteristik yang dimiliki bahasa jurnalistik yakni sederhana, singkat, padat, lugas, jelas, jernih, menarik, demokratis, populis, logis, gramatikal, mengesampingkan kata tutur, mengesampingkan kata dan istilah asing, pemilihan diksi yang tepat, menghindari kalimat pasif, mengesampingkan kata atau istilah teknis, dan tunduk kepada kaidah etika (Sumadiria, 2018).

Menurut wawancara dengan Salman Mardira selaku editor kanal perjalanan, Okezone.com menjadikan bahasa jurnalistik sebagai pedoman penulisan serta penyuntingan berita. Bahasa yang digunakan Okezone.com umumnya bersifat ringkas, lugas, dan mudah dipahami. Poin karakteristik "mudah dipahami" pada gaya bahasa Okezone.com erat hubungannya dengan segmentasi pembaca yang dimiliki. Mengingat Okezone.com, terutama kanal perjalanan, menargetkan golongan muda atau generasi milenial sebagai pembaca, bahasa yang digunakan pun disesuaikan dengan kebutuhan baca mereka. Kanal perjalanan Okezone.com terkadang menggunakan kata yang sedang naik daun di kalangan masyarakat atau sering digunakan dalam media sosial, meskipun kata tersebut tidak termasuk bahasa baku. Selain itu, Okezone.com juga tidak melupakan hakikatnya sebagai media siber yang memiliki dua jenis pembaca, yaitu manusia dan mesin pencari. Saat menulis untuk media siber, jurnalis harus menggunakan bahasa yang dimengerti serta mudah ditangkap oleh mesin pencari.

Tidak hanya isinya, menulis judul berita juga mempunyai aturan. Menurut Abdul Chaer (2010), hal yang patut diperhatikan dalam penulisan judul berita, di antaranya adalah: (1) menanggalkan prefiks me- atau ber- pada kata kerja demi menghemat kata; (2) menggunakan kalimat aktif; (3) bersifat ringkas dan padat; (4) harus selaras dengan fakta-fakta yang ada dalam berita. Gaya bahasa media siber dewasa ini identik dengan clickbait atau umpan klik, yaitu pancingan untuk menarik perhatian pembaca dan mendorongnya agar mengklik judul berita. Ciri khas clickbait antara lain bersifat sensasional, berbentuk kalimat tanya, menggunakan kata penunjuk "ini", "inilah", atau "ini dia", dan menggunakan interjeksi "wow!", “keren!”, “duh!”, ataupun “astaga!”. Clickbait dianggap tidak efektif dan menggambarkan jurnalisme tidak bertanggung jawab (Romli, 2020).

Berdasarkan analisis yang dilakukan penulis, judul berita yang diterbitkan kanal perjalanan Okezone.com memiliki karakteristik serupa dengan yang disampaikan Abdul Chaer dalam bukunya Bahasa Jurnalistik (2010). Okezone.com menghapus prefiks me- atau ber- dalam penulisan judul berita demi menghemat bahasa dan memadatkan kalimat, menggunakan kalimat aktif, dan menyesuaikannya dengan isi berita. Contoh judul berita yang ditayangkan pada kanal perjalanan Okezone.com di antaranya adalah Bau Menyengat dari Dinding Pesawat Bikin Penumpang Panik, Penerbangan Ditunda (terbit pada 16 September 2021) dan Cile Buka Kembali Perbatasan Dongkrak Sektor Pariwisata (terbit pada 16 September 2021).

Namun, clickbait atau umpan klik yang disebut penggambaran dari jurnalisme tidak bertanggung jawab pun ditemukan pada sejumlah berita terbitan kanal perjalanan Okezone.com. Beberapa judul-judul berita yang dimiliki kanal Okezone.com bersifat tanya, menggunakan kata penunjuk, maupun kata seru. Contohnya ada pada berita yang diterbitkan 18 September 2021 berjudul Masinis Dihukum Gara-Gara Buang Air Besar, Kok Bisa? 
Fatha Annisa, Ahmad Junaidi: Implementasi Bahasa Jurnalistik pada Media Siber (Analisis Wacana pada Berita Okezone.com Kanal Perjalanan)

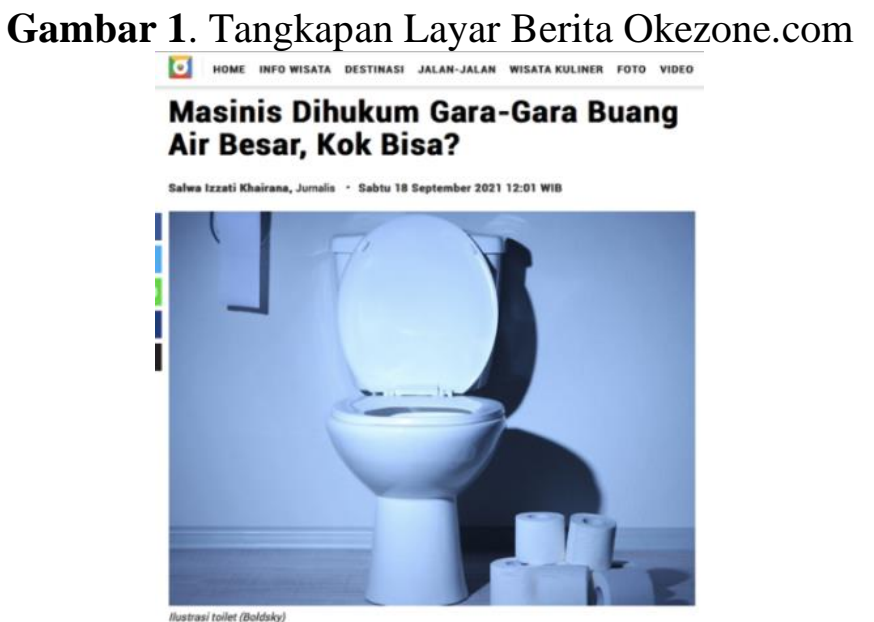

Sumber: Dokumentasi Pribadi

Kalimat tanya pada judul tidak sesuai dengan hakikat berita yang seharusnya memberikan informasi, bukan bertanya kepada pembaca. Oleh karena itu, judul berita di atas dapat diganti dengan: Masinis Dihukum Gara-Gara Buang Air Besar.

Teras berita menjadi unsur penting lainnya dalam keseluruhan berita. Dalam Karya Latihan Wartawan (KLW) ke-13 pada Oktober 1977, Persatuan Wartawan Indonesia mengemukakan 10 pedoman penulisan teras berita. Pedoman tersebut antara lain (Chaer, 2010): (1) menempati paragraf pertama, memuat pokok terpenting berita, dan terdiri tidak lebih dari tiga kalimat; (2) tidak dianjurkan memiliki lebih dari 30 sampai 45 kata; (3) ditulis dengan susunan kalimat yang singkat dan sederhana, serta membawa prinsip satu gagasan dalam satu kalimat; (4) tidak menyertakan informasi tidak mendesak; (5) sebaiknya memuat unsur apa; (6) bisa diawali dengan unsur siapa; (7) unsur waktu disertakan dalam teras berita jika bermakna dalam berita yang akan ditulis; (8) mengutamakan unsur tempat dibanding unsur waktu; (9) tidak menulis unsur mengapa dan bagaimana; (10) pernyataan seseorang dapat dimuat dalam teras berita asalkan bukan kalimat yang kompleks.

Dari analisis yang dilakukan terhadap 70 berita yang ditayangkan pada kanal perjalanan Okezone.com edisi 1 sampai 30 September 2021, penulis menemukan beberapa berita tidak memiliki teras berita sesuai dengan pedoman yang ditentukan Persatuan Wartawan Indonesia (PWI). Teras berita kerap kali memiliki lebih dari 30 kata, sehingga paragraf menjadi tidak padat dan tidak sederhana. Bahkan pada salah satu berita berjudul Viral Pengunjung Nyaris Terseret Ombak saat Piknik di Pantai, Ending-nya bikin Ngenes!, berita ini diterbitkan pada 23 september 2021, teras berita tidak mewakili isi berita yang ada.

Secara keseluruhan dapat dikatakan bahwa meskipun Kanal Perjalanan Okezone.com berpedoman pada bahasa jurnalistik dan tata aturan penulisan berita yang berlaku, sejumlah kesalahan penggunaan bahasa jurnalistik dalam judul, teras, maupun isi berita (edisi 1-30 September 2021) tetap ditemukan. Kesalahan tersebut antara lain bersifat: (1) tidak sederhana; (2) tidak lugas; (2) penggunaan bahasa asing yang tidak diikuti dengan penjelasan maupun tata penulisan yang benar; (3) kekeliruan diksi; (4) tidak tunduk pada kaidah etika; (5) tidak tepat secara gramatikal; (6) tidak mengutamakan kalimat aktif. Beberapa judul berita juga bersifat clickbait, sehingga menunjukkan jurnalisme yang tidak bertanggung jawab. Contoh salah satu dari 70 berita Kanal Perjalanan Okezone.com edisi 1-30 
September 2021 yang tidak sesuai dengan karakteristik bahasa jurnalistik dan bersifat clickbait ada pada berita berjudul 4 Pose Pramugari Sherin Oviani bak Model Papan Atas, Netizen: Pahanya Bening! yang tayang pada 18 September 2021.

Gambar 2. Tangkapan Layar Berita Okezone.com

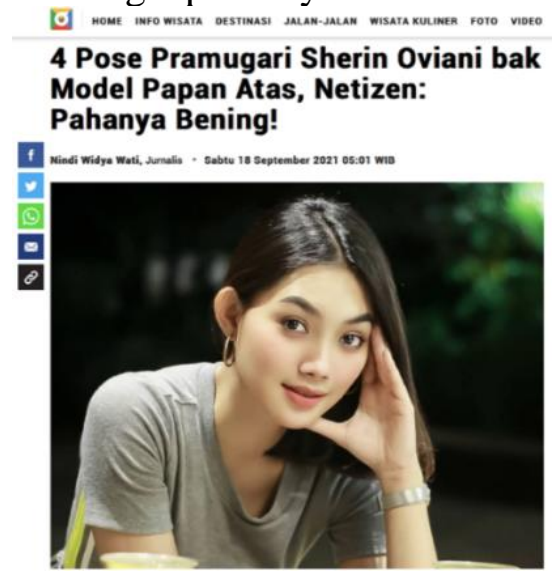

Sumber: Dokumentasi Pribadi

Kata "Pahanya Bening" tidak tunduk pada kaidah etika, karena bersifat tidak sopan dan memiliki maksud terselubung untuk menciptakan fantasi seksual khalayak pembaca. Judul berita tersebut dapat diganti dengan 4 Pose Pramugari Sherin Oviani bak Model Papan Atas. Kesalahan serupa juga ditemukan pada berita berjudul 4 Potret Cantik Pramugari Eliska Parker, Netizen: Mulus Kaki yang diterbitkan pada 12 September 2021. Kata "Mulus Kaki" tidak sesuai dengan kaidah etika, karena bersifat tidak sopan. Judul tersebut dapat diubah menjadi 4 Potret Cantik Pramugari Eliska Parker.

Gambar 3. Tangkapan Layar Berita Okezone.com

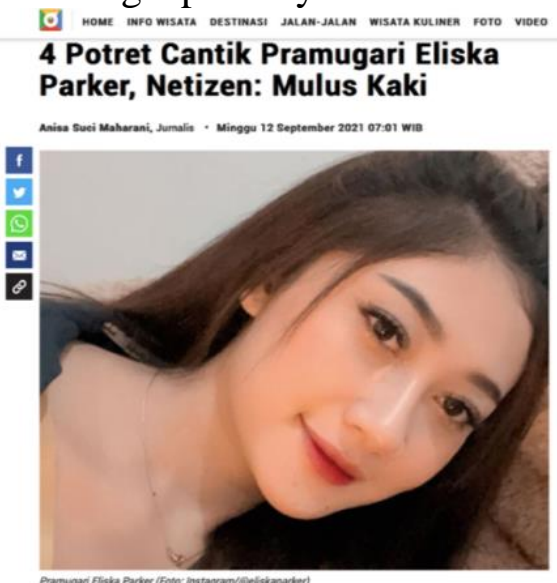

Sumber: Dokumentasi Pribadi

Contoh kesalahan pengimplementasian bahasa jurnalistik lainnnya ditemukan pada berita berjudul "Heboh Rambut Keluar dari Makam Berusia 1 Abad Bikin Merinding" yang terbit pada 22 September 2021. Selain penggunaan kata "heboh" yang membuat judul tersebut bersifat clickbait, kesalahan lain terdapat pada teras berita. Dalam teras berita tersebut ada kalimat yang berbunyi: "ia sangat ketakutan setelah tersandung kuburan berusia 100 tahun alias satu abad. Yang buatnya kaget 
bukan kepalang ialah ia melihat rambut ..." Kalimat tersebut bersifat boros dan dapat disederhanakan dengan menghapus kata "alias satu abad" atau "100 tahun" serta mengganti kata "yang buatnya kaget bukan kepalang" menjadi "pasalnya." Kalimat lantas akan tertulis: "ia sangat ketakutan setelah tersandung kuburan berusia 100 tahun. Pasalnya, ia melihat rambut ..." atau "ia sangat ketakutan setelah tersandung kuburan berusia satu abad. Pasalnya, ia melihat rambut ..."

Gambar 4. Tangkapan Layar Berita Okezone.com

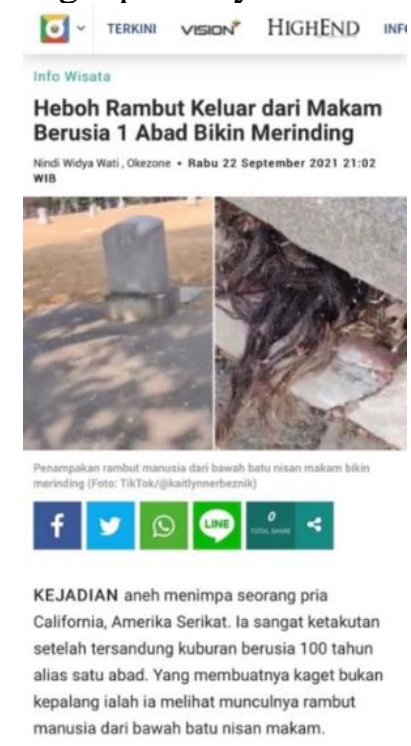

Sumber: Dokumentasi Pribadi

Pada paragraf empat di berita yang sama, bahasa jurnalistik kembali tampak tidak diimplementasikan dengan seharusnya. Jurnalis menggunakan kalimat pasif pada kalimat yang sebenarnya dapat ditulis dengan kalimat aktif, supaya lebih mudah dicerna pembaca. Kalimat tersebut berbunyi: "Menjadi hal yang benar-benar menyeramkan, ketika pengalaman itu terjadi di area Pemakaman Katolik Saint Joseph, Sacramento". Jika dikoreksi lagi, kalimat tersebut dapat diubah menjadi: "Pengalaman itu menjadi hal yang benar-benar menyeramkan karena terjadi di area Pemakaman Katolik Saint Joseph, Sacramento."

Gambar 5. Tangkapan Layar Berita Okezone.com

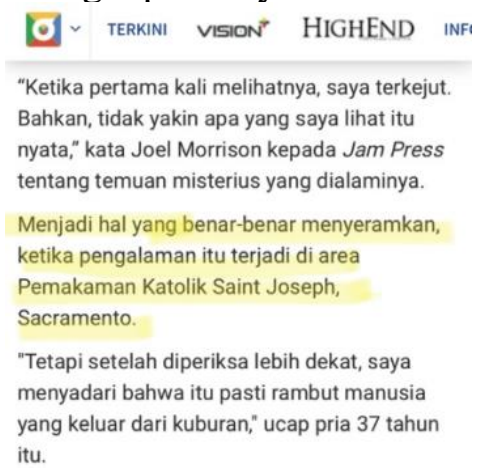

Sumber: Dokumentasi Pribadi

Salman Mardira selaku editor kanal perjalanan Okezone.com mengungkapkan media siber dituntut serba cepat dalam menyajikan berita agar 
selalu up to date. Hal ini yang menjadi salah satu pemicu terjadinya kesalahan penulisan, sehingga kata yang digunakan tidak sesuai dengan Ejaan Yang Disempurnakan (EYD) ataupun karakteristik bahasa jurnalistik. Kesalahan seperti itu diakuinya berpengaruh negatif pada minat baca publik. Jika kesalahan terdapat pada kata kunci, maka secara otomatis mesin pencari juga akan kesulitan mendeteksi kata bahkan keseluruhan berita tersebut.

Dalam mengatasi terjadinya kesalahan tersebut, berita yang akan diterbitkan pada kanal perjalanan Okezone.com akan melewati proses penyuntingan terlebih dahulu. Di sana naskah akan dicek kembali keberadaan unsur-unsur beritanya, kebenaran logika bahasanya, penempatan kalimat, alur berita, serta penulisan. Setelah lolos tahap tersebut, naskah berita baru dapat dipublikasi. Berita yang sudah tayang pun tetap dibaca ulang oleh editor dan rekan-rekan satu tim untuk memastikan jika benar-benar tidak ada kesalahan. Namun jika ternyata ada kesalahan yang terselip, berita akan ditarik kembali untuk diralat dan disunting.

\section{Simpulan}

Berdasarkan hasil analisis dan wawancara yang dilakukan peneliti, maka kesimpulan yang dapat ditarik dari penelitian ini adalah Kanal Perjalanan Okezone.com menjadikan bahasa jurnalistik sebagai pedoman penulisan dan penyuntingan berita. Namun, masih ditemukan kesalahan pengimplementasian bahasa jurnalistik dalam 17 dari total 70 berita pada kanal perjalanan edisi 1-30 September 2021 yang dianalisis, antara lain berbentuk: (1) tidak sederhana; (2) tidak lugas; (3) penggunaan bahasa asing yang tidak diikuti dengan penjelasan maupun tata penulisan yang benar; (4) kekeliruan diksi; (5) tidak tunduk pada kaidah etika; (6) tidak tepat secara gramatikal; (7) tidak mengutamakan kalimat aktif. Beberapa judul berita juga bersifat clickbait.

Sejumlah ketidaksesuaian bahasa dalam berita Kanal Perjalanan Okezone.com dengan karakteristik bahasa jurnalistik, seperti bahasa asing, bahasa yang tengah naik daun di kalangan masyarakat dan tidak sesuai dengan Kamus Besar Bahasa Indonesia (KBBI), sengaja digunakan untuk menyesuaikan kebutuhan target pembaca maupun kata kunci dalam mesin pencari, sehingga berita lebih mudah ditemukan oleh calon pembaca. Selain itu, diketahui bahwa Kanal Perjalanan Okezone.com melakukan penyuntingan naskah berita terlebih dahulu sebelum mempublikasikannya. Setelah tayang, berita akan dibaca kembali oleh editor serta rekan satu tim untuk memastikan tidak ada kesalahan. Jika ternyata ada kesalahan yang terselip, berita akan ditarik kembali untuk diralat dan disunting.

\section{Ucapan Terima Kasih}

Peneliti mengucapkan terima kasih kepada Fakultas Ilmu Komunikasi Universitas Tarumanagara, narasumber, serta semua pihak yang turut membantu peneliti sehingga penelitian ini dapat diselesaikan.

\section{Daftar Pustaka}

Alexa.com. (n.d.). Top Sites in Indonesia. Retrieved from Alexa.com website: https://www.alexa.com/topsites/countries/ID

Aryusmar. (2011). Karakteristik Bahasa Jurnalistik dan Penerapannya pada Media 
Cetak. HUMANIORA, 2(2), 1209-1218. https://doi.org/https://doi.org/10.21512/humaniora.v2i2.3172

Chaer, A. (2010). Bahasa Jurnalistik. Jakarta: Rineka Cipta.

Eriyanto. (2006). Analisis Wacana: Pengantar Analisis Teks Media. Yogyakarta: Lkis.

Fadilah, N., \& Mony, H. (2020). Penerapan Bahasa Indonesia Jurnalistik di Media Online. Jurnal Ilmu Komunikasi, 2(1), 1-19. Retrieved from http://jurnal.usahid.ac.id/index.php/ilmu_komunikasi/article/view/297/265

Moleong, L. J. (2011). Metodologi Penelitian Kualitatif. Bandung: Remaja Rosdakarya.

Pebrianto, F. (2021). Bisnis Media MNC, Hary Tanoe Sebut Jumlah Pemirsa TV Meningkat Sangat Luar Biasa. Retrieved from Tempo website: https://bisnis.tempo.co/read/1430838/bisnis-media-mnc-hary-tanoe-sebutjumlah-pemirsa-tv-meningkat-sangat-luar-biasa/full\&view=ok

Pers, D. (n.d.). Data Perusahaan Pers. Retrieved from https://dewanpers.or.id/data/perusahaanpers\%09

Romli, A. S. M. (2020). Jurnalistik Online: Panduan Mengelola Media Online. Bandung: Nuansa Cendekia.

Silalahi, R. Y., \& Susanto, E. H. (2020). Penerapan Kode Etik Jurnalistik Media Online Tribunnews dan Efek Pemberitaan pada Pembacanya. Koneksi, 4(2), 293-300. https://doi.org/10.24912/kn.v4i2.8144

Sugiyono. (2015). Metode Penelitian Pendidikan (Pendekatan Kuantitatif, Kualitatif, dan $R \& D)$. Bandung: Alfabeta.

Sumadiria, A. S. H. (2006). Bahasa Jurnalistik: Panduan Praktis Penulis dan Jurnalis. Bandung: Simbiosa Rekatama Media.

Sumadiria, A. S. H. (2018). Bahasa Jurnalistik: Panduan Praktis Penulis dan Jurnalis. Bandung: Simbiosa Rekatama Media.

Yundri, S., \& Nasution, B. (2018). Implementasi Bahasa Jurnalistik Pada Pemberitaan Hukum Dan Kriminal Portal Berita Www.goriau.com. JOM FISIP, 5(1), 1-7. $\quad$ Retrieved from https://media.neliti.com/media/publications/207121-none.pdf 